\title{
SOSIALISASI INOVASI APE (ALAT PERMAINAN EDUKATIF) BAGI GURU RA SE-KECAMATAN PLERED DAN TEGALWARU PADA MASA PANDEMI COVID-19
}

\author{
Annisa Purwani \\ Program Studi Pendidikan Islam Anak Usia Dini, STAI DR. KHEZ. Muttaqien \\ e-mail: Fasa.ap@gmail.com
}

DOI: doi.org/10.52593/svs.02-1-04

Naskah diterima: 04 November 2021, direvisi: 14 Desember 2021, disetujui: 26

Januari 2022

Abstract Early childhood education in the golden age is very important because at this time children's intelligence is growing rapidly. The stimulation given is not only for cognitive intelligence but also for social emotional, character, and noble character needs to be stimulated. The role of teachers and parents in facilitating children when providing learning stimuli through their experiences needs to be designed and arranged in such a way that all aspects of children's development can develop optimally, therefore there is a need for educational game tools as learning facilities for early childhood. APE innovation socialization was carried out to RA teachers in Plered and Tegalwaru sub-districts in two stages, namely presentation and training, the first stage was in the form of exposure to the importance of APE in the learning process in early childhood, the second stage was training involving participants in carrying out APE innovation-making activities in developing all aspects early childhood development. Based on the results of the analysis of the interview and observation data, it was revealed that the creativity of teachers in making APE innovations could increase not only by providing material but also participants being directly involved in the manufacturing process and sharing innovations with colleagues so that innovation could develop.

Inovation, learning, $A P E$

Abstrak

Pendidikan pada anak usia dini di masa golden age sangat penting karena pada masa ini kecerdasan anak sangat berkembang dengan pesat. Rangsangan yang diberikan bukan hanya untuk kecerdasan kognitifnya saja tetapi sosial emosional, budi pekerti, dan akhlak mulia pun perlu diberikan rangsangannya. Peran guru dan orang tua dalam memfasilitasi anak saat memberikan rangsangan belajar melalui pengalamannya perlu dirancang dan ditata sedemikian rupa sehingga seluruh aspek perkembangan anak dapat berkembang secara optimal, oleh karena itu perlu adanya alat permainan edukatif sebagai fasilitas belajar pada anak usia dini. Sosialisasi inovasi APE dilakukan kepada guru RA kecamatan Plered dan Tegalwaru dalam dua tahap yaitu presentasi dan pelatihan, tahap pertama berupa pemaparan tentang pentingnya APE dalam proses pembelajaran pada anak usia dini, tahap kedua yaitu pelatihan melibatkan peserta dalam melakukan kegiatan pembuatan inovasi APE dalam mengembangkan seluruh aspek perkembangan anak usia dini. Berdasarkan hasil analisis dari data wawancara dan observasi mengungkapkan bahwa kreatifitas guru dalam pembuatan inovasi APE dapat meningkat bukan hanya pemberian materi saja tetapi peserta juga ikut terlibat secara langsung dalam proses pembuatannya serta saling berbagi inovasi dengan teman sejawat sehingga inovasi dapat berkembang. 


\section{PENDAHULUAN}

Sistem pembelajaran yang dilakukan oleh seluruh lembaga pendidikan khususnya pada anak usia dini menuntut guru dan kepala sekolah untuk terus meningkatkan kreativitas dan inovasi pada masa pandemi covid-19. Kebijakan pemerintah yang dikeluarkan untuk lembaga pendidikan anak usia dini yaitu pembelajaran yang dilakukan harus menggunakan sistem daring/online dimana anak diberikan kesempatan untuk melakukan pembelajaran melalui video call/zoom/google classroom dan lain sebagainya. Namun tidaklah mudah bagi anak usia dini untuk dapat mengikuti pembelajaran secara daring padahal pendidikan usia dini merupakan priode kritis bagi anak karena sangat berpengaruh terhadap perkembangan periode berikutnya hingga masa dewasa, sementara masa emas ini hanya datang sekali (Nurhayadi \& Aditiya Agasi, 2020), selain itu pembelajaran anak usia dini harus disajikan dengan semenarik mungkin sehingga terciptanya pembelajaran yang menyenangkan. Oleh karena itu bukan hanya kesulitan bagi anak untuk mengikuti pembelajaran secara online namun ternyata kesulitan pun dihadapi oleh guru, tentu saja guru harus selalu meningkatkan kemampuan dalam mengajar sehingga pembelajaran tidak monoton dan tidak jenuh selama masa pandemi, ironinya dari 2,92jt guru hanya $51 \%$ yang berpendidikan sarjana atau lebih sisanya belum berpendidikan sarjana (Latuconsina, 2014), artinya kemampuan guru agar pembelajaran tidak monoton dan membosankan masih jauh dari harapan. Sudah menjadi rahasia umum ketika seseorang melakukan hal yang monoton akan mengalami kebosanan dan kejenuhan, begitu pula dengan pembelajaran meskipun dalam kegiatannya belajar adalah aktivitas berpikir tapi jika aktivitas tersebut berlangsung secara terus menerus tanpa adanya inovasi dan variasi jelas akan mengalami kebosanan (Widiaswori, 2020).

Selain minimnya inovasi dan kreatifitas guru, hal lain yang menjadi dilema adalah rendahnya capaian perkembangan dalam pembelajaran. Penilaian pada anak usia dini dilakukan dengan mengadakan suatu pengamatan, pencatatan dan dokumentasi tentang kegiatan anak. Penilaian tidak ahanya dilakukan untuk mengukur keberhasilan suatu perogram akan tetapi memantau kemajuan dan perkembangan belajar anak yang dilakukan secara bertahap dan berkesinambungan (Fauziyah, 2021). Kondisi tersebut diperparah dengan kendala-kendala yang terjadi akibat covid-19 seperti keterbatasan konektivitas jaringan, tingginya kebutuhan kuota internet yang menjadi kendala serius dari masyarakat ekonomi rendah, dan kurangnya keterampilan dalam menggunakan teknologi informasi yang dihadapi oleh guru. Ketersediaan gawai atau alat elektronik sebagai penunjang pembelajaran daring menjadi persoalan hambatan dalam pembelajaran jarak jauh. Pembelajaran daring di daerah pelosok dengan keterbatasan teknologi dan jaringan internet, sehingga pembelajaran tidak berjalan secara optimal (Rahayu \& Syahidul Haq, 2021). Bagi masyarakat perkotaan bukanlah hal yang sulit untuk mengakses jaringan dan hampir seluruh anak-anaknya memiliki fasilitas technology dimana setiap anggota keluarga memiliki handphone berbeda halnya permasalahan yang terjadi di daerah perkampungan di setiap keluarga belum tentu setiap anak sudah mempunyai handphone apalagi untuk membeli kuota dan mendapat jaringan saja masyarakat masih sulit. Bahkan jika orangtua peserta didik harus bekerja di luar rumah tidak ada yang dapat membantu anak-anak untuk diberikan fasilitas technology sehingga pembelajaran sangat sulit dilakukan akhirnya guru harus mencari strategi agar pembelajaran dapat tersampaikan sehingga perkembangan anak dapat tercapai. Bahkan banyaknya orangtua yang terkena PHK akibat pandemi covid-19.

Bagi pelajar yang sudah dewasa mungkin dapat bekerjasama untuk melaksanakan pembelajaran daring namun beda hal nya dengan anak usia dini selain guru harus bekerjasama dengan murid, guru pun harus bekerjasama dengan orangtua agar capaian pembelajaran dapat tercapai. Oleh karena itu anak dan orangtua dapat diberikan APE yang dapat mewakili guru sebagai sarana penyampai informasi pengetahuan sehingga orangtua dan anak dapat bekerjasama untuk mendapat informasi pengetahuan dari guru tersebut sehingga capaian perkembangan anak dapat berjalan sesuai dengan tujuan pembelajaran. 
Peneliti melakukan kegiatan pengabdian masyarakat kepada guru-guru RA di kecamatan Plered dan Tegalwaru agar guru-guru senantiasa mendapat pencerahan, inovasi, dan kreatifitas untuk terus memberikan pembelajaran yang menyenangkan kepada peserta didik khususnya di lembaga pendidikan anak usia dini.

\section{METODE}

Kegiatan sosialisasi dilaksanakan menggunakan metode presentasi dan pelatihan. Sasaran peserta dalam kegiatan sosialisasi ini dibatasi karena pada masa pandemi covid-19 menyesuaikan dengan maximum kapasitas ruangan yang tersedia sehingga peserta yang mengikuti kegiatan sosialisasi ini adalah : (1) Kepala sekolah atau guru RA sebagai perwakilan dari sekolah yang berada di lingkungan Kecamatan Plered; (2) Kepala sekolah atau guru RA sebagai perwakilan dari sekolah yang berada di lingkungan Kecamatan Tegalwaru; (3) Seluruh guru RA Saeful Hidayah karena sekolah ini sebagai salah satu sekolah yang bekerjasama dengan STAI DR. KH.EZ Muttaqien untuk memberikan izin kepada mahasiswa melakukan praktek lapangan di sekolah tersebut, ada dua tahapan dalam kegiatan sosialisasi yang dilakukan. Tahap pertama merupakan kegiatan presentasi, pada kegiatan ini memuat sesi pemaparan dan diskusi tanya jawab mengenai pentingnya guru memiliki kreatifitas dalam berinovasi membuat APE untuk kegiatan belajar mengajar di Lembaga Pendidikan Anak Usia Dini. Hal ini dilakukan agar peserta dapat mengembangkan pola pikir secara lebih terbuka dalam melakukan pengajaran di sekolah. Pada tahap pertama kegiatan diawali dengan dengan meminta peserta untuk bernyanyi kemudian meminta peserta untuk memberikan argumentasi tentang motivasi mengajar di Lembaga Pendidikan Anak Usia Dini. Selanjutnya pemaparan materi mengenai pentingnya pembelajaran pada anak usia dini serta perlunya penggunaan APE dalam proses belajar mengajar di Lembaga Pendidikan Anak Usia Dini. Pada tahap presentasi selain pemaparan juga adanya sesi diskusi atau tanya jawab dengan para peserta. Para peserta diberi kesempatan untuk bertanya dan mengutarakan keluhan yang menjadi hambatan proses pembelajaran pada masa pandemi covid-19 khususnya di Lembaga Pendidikan Anak Usia DINI. Dalam tahap pertama diberikan juga masukan dan saran kepada peserta mengenai pembuatan APE yang sederhana menggunakan alat dan bahan yang tersedia di sekolah. Selanjutnya yaitu tahp kedua merupakan pelatihan dengan melibatkan seluruh peserta dalam membuat inovasi APE. Pada tahap kedua ini peserta dibagi kedalam 4 kelompok dimana peserta mengambil alat dan bahan yang sudah di sediakan oleh panitia kemudian peserta menentukan tema pembelajaran dan capaian perkembangan apa saja yang akan dikembangkan melalui APE yang dibuat oleh masing-masing kelompok. Pada tahap pembagian kelompok masing-masing peserta dibebaskan untuk memilih anggota kelompoknya selanjutnya masing-masing kelompok menentukan APE yang akan dibuat adapun APE yang dibuat oleh setiap kelompok yaitu sebagai berikut: (a) Kelompok binatang membuat binatang laut; (b) kelompok tanaman membuat pohon tempel; (c) kelompok rumahku membuat puzzle bentuk geometri; (d) kelompok kendaraan mebuat pesawat. Peserta diberikan waktu sekitar satu jam untuk membuat inovasi APE selanjutnya masing-masing kelompok mempresentasikan hasil APE yang sudah dibuat dengan menjelaskan juga perkembangan apa saja yang dapat dikembangkan melalui APE tersebut kemudian ada sesi tanya jawab dengan kelompok lain untuk mengeksplorasi dalam menggunakan alat dan bahan lain dalam pembuatan APE yang sama. Hal ini diharapkan agar peserta mampu membuat berbagai macam inovasi APE dalam pembelajaran di Lembaga Pendidikan Anak Usia Dini sehingga pencapaian perkembangan anak dapat berkembang secara optimal.

\section{HASIL DAN PEMBAHASAN}

Kegiatan sosialisasi dilaksanakan dalam dua tahapan namun tetap di hari yang sama dan di lokasi yang sama. Kegiatan dilaksanakan pada tanggal 26 Februari 2021 berlokasi di RA Darussalam Kecamatan Plered Kabupaten Purwakarta. Peserta yang 
mengikuti kegiatan sosialisasi ini yaitu : (1) Kepala sekolah atau guru RA sebagai perwakilan dari sekolah yang berada di lingkungan Kecamatan Plered; (2) Kepala sekolah atau guru RA sebagai perwakilan dari sekolah yang berada di lingkungan Kecamatan Tegalwaru; (3) Seluruh guru RA Saeful Hidayah karena sekolah ini sebagai salah satu sekolah yang bekerjasama dengan STAI DR. KH.EZ Muttaqien sebagai tempat PPL mahasiswa. Secara umum kegiatan ini diikuti sesuai dengan sasaran kegiatan yakni guru RA yang berada di Kecamatan Plered dan Kecamatan Tegalwaru namun ternyata ada dua orang yang hadir dari mahasiswa Universitas Pendidikan Indonesia Kampus Purwakarta karena diwajibkan untuk mengikuti seminar yang terkait dengan pendidikan anak usia dini namun masih dalam kategori sesuai sasaran karena ini pula menjadi bekal mahasiswa paud dalam berinovasi mengembangkan kemampuan dalam pembuatan APE. Permasalahan yang menjadi keluhan dari guru RA yaitu kurangnya fasilitas untuk menunjang kegiatan pembelajaran sehingga pembelajaran selama masa pandemi hanya dapat diberikan tugas saja sedangkan pembelajaran pada anak usia dini hendaknya harus menarik, dan konkrit. Begitu pula orang tua dalam mengajarkan kepada anak di rumah sangat tidak ada yang dapat membantu atau memfasilitasi alat untuk menyelesaikan tugas-tugas anak selama belajar dirumah. Sejumlah pengakuan dari peserta yang hadir kebetulan mahasiswa merasakan tidak banyak memperoleh pengetahuan dan keterampilan secara tatap muka, kemudian mereka memahami kondisi yang ada di lingkungannya sehingga mereka dapat mengetahui problematika kesulitan pembelajaran di masa pandemi, selain itu mereka mengeluhkan kurangnya kegiatan yang diselenggarakan untuk dihadiri oleh mahasiswa secara langsung karena jika kegiatan seminar dilakukan secara online mereka tidak cukup puas dalam memahami isi materi belum lagi masalah akses, jaringan, keuangan, dan koneksi internet yang belum cukup memadai di area perkampungan. Oleh karena itu kesempatan bagi mereka untuk mengikuti kegiatan sosialisasi ini dengan tatap muka terbatas. Hal tersebut mengakibatkan pengetahuan tentang inovasi APE tidak mengalami peningkatan.

Kendala yang ditemukan melalui wawancara dan observasi yaitu banyaknya guru yang tidak menggunakan APE sebagai alat untuk menyampaikan informasi kepada peserta didiknya, guru hanya memberikan tugas lembar kerja/majalah saja selama masa pandemi. Beberapa faktor terjadinya permasalahan tersebut diantaranya yaitu : (1) kurangnya dana untuk membuat APE di sekolah; (2) Kurangnya apresiasi yang diberikan oleh guru dalam membuat inovasi APE; (3) Kurangnya fasilitas teknologi seperti leptop/komputer yang digunakan oleh guru dalam menyampaikan informasi kepada peserta didik; (4) Sedikitnya alat dan bahan yang tersedia di sekolah untuk dijadikan bahan membuat APE; (5) Hanya mengandalkan APE dari bantuan pemerintah; (6) tidak ada kegiatan outing class karena tidak ada pembelajaran tatap muka. Hal ini menjadi kendala yang penting karena faktor permasalahan yang terjadi tidak dapat meningkatkan kualitas guru dalam berinovasi membuat alat permainan edukatif untuk menunjang pembelajaran di sekolah. Kurangnya inovasi APE dalam pembelajaran menimbulkan capaian perkembangan anak tidak berkembang secara optimal sehingga dikhawatirkan banyak anak yang berhenti sekolah akibat tidak ada pencapaian apapun dari dampak belajar dirumah, belum lagi yang menjadi kendala lainnya yaitu banyak anak yang diasuh oleh pengasuh (nenek atau saudara) karena sebagian orangtua harus bekerja di pabrik sehingga pengasuh tidak dapat mengajarkan tugas-tugas yang diberikan oleh sekolah kepada anak di rumah. Hasil wawancara dan observasi berikut ini menjadi masalah yang timbul akibat pembelajaran yang monoton selama masa pandemi diataranya yaitu : (1) Rendahnya ketercapaian perkembangan peserta didik; (2) Sulitnya orangtua mengajarkan kepada anak ketika selama masa pembelajaran di rumah; (3) Terbatasnya fasilitasi handphone dan leptop untuk belajar dirumah; (4) 
Rendahnya penghasilan orangtua akibat pandemi sehingga orangtua banyak yang tidak menyanggupi pembiayaan untuk membeli paket internet; (5) kurangnya akses internet untuk mengakses pembelajaran secara online. agar peserta didik dapat meningkatkan capaian perkembangannya harus mengadakan suatu kegiatan yang berkaitan dengan pelatihan pembuatan inovasi APE secara tatap muka walaupun terbatas, karena jika kegiatan ini dilakukan secara daring peserta sangat sulit untuk mengikuti kegiatan sosialisasi dan pelatihan seperti ini kemudian kegiatan sosialisasi ini harus didukung oleh seluruh Lembaga baik pemerintahan, universitas, maupun organisasi lainnya untuk mengadakan acara sosialasi dan pelatihan guna mengembangkan kemampuan guru dalam berinovasi di Lembaga Pendidikan Anak Usia Dini demi terciptanya proses pembelajaran yang menyenangkan bagi anak. Khusus mengenai sosialisasi yang menjadi kebutuhan peserta perlu memerhatikan beberapa hal berikut yaitu : (1) informasi yang disajikan tidak hanya teori tetapi sebuah keadaan real di lapangan agar dapat diterima oleh peserta; (2) tempat lokasi memungkinkan untuk terselenggaranya acara sosialisasi; (3) materi yang disajikan harus menarik sehingga peserta tidak bosan untuk mengikuti kegiatan sosialisasi; (4) penggunaan bahasa yang sederhana dan mudah difahami oleh peserta; (5) kegiatan diselingi dengan bernyanyi agar guru termotivasi untuk berinovasi; (6) menumbuhkan motivasi untuk terus berinovasi dalam membuat APE; (7) mensosialisasikan kepada peserta bahwa membuat APE tidak harus mengeluarkan banyak biaya karena APE dapat dibuat dengan alat dan bahan yang tersedia di sekolah. Kegiatan sosialisasi yang diperlukan oleh peserta bukan hanya pemaparan teori-teori karena jika tidak diberikan pelatihan teori tersebut tidak bisa diterapkan kepada peserta didik di sekolah, selain itu kegiatan sosialisasi yang perlu diperhatikan ialah kegiatan harus menarik, penyampaian materi yang sederhana, dan membuat peserta tertarik untuk terus berinovasi dalam pembuatan APE. Pelaksanaan kegiatan sosialisasi bagi guru RA dilakukan melalui dua tahapan yaitu presentasi untuk memaparkan materi mengenai pentingnya pembuatan APE, setelah pemaparan materi ada sesi tanya jawab seputar kesulitan dalam membuat APE di sekolah. Kegiatan tahap kedua dilanjutkan dengan pelatihan membuat APE dengan bahan yang sudah disediakan oleh panitia, seluruh peserta diminta untuk berkelompok membentuk empat kelompok kemudian menentukan tema pembelajaran dan aspek perkembanngan apa saja yang akan dikembangkan melalui APE yang dibuat, setelah itu masing-masing kelompok diberi kesempatan untuk mengambil alat dan bahan yang sudah tersedia dihadapan peserta kemudian peserta diminta untuk mempresentasikan hasil APE yang sudah dibuat dengan menjelaskan tema pembelajaran dan aspek-aspek perkembangan yang dikembangkan melalui APE tersebut. Setelah pemaparan dari peserta selesai selanjutnya peserta diberi kesempatan untuk tanya jawab seputar alat dan bahan jika digunakan menggunakan bahan yang berbeda tak lupa juga peserta memaparkan kesan dan pesan dalam mengikuti acara sosialisasi tersebut. hal ini dimaksudkan agar setiap peserta memiliki motivasi untuk terus berinovasi dalam meningkatkan mutu pembelajaran di Lembaga Pendidikan Anak Usia Dini. Pelaksanaan kegiatan sosialisasi berjalan sesuai dengan rencana yang telah disusun, berjalan dengan sangat kondusif, dan menyenangkan.

Antusiasme para peserta dalam kegiatan sosialisasi pun sangat bagus begitu juga dengan konsistensi peserta mengikuti acara sosialisasi dari awal sampai akhir sangat baik. Bukti pemahaman peserta terhadap inovasi pembelajaran dalam 
pembuatan APE terlihat ketika setiap kelompok memaparkan hasil APE yang dibuat sekaligus pemaparan tujuan dibuatnya APE dan aspek apa saja yang akan dikembangkan dari pembuatan APE tersebut. hal ini menunjukan bahwa motivasi peserta untuk mengikuti pelatihan dan materi yang diterima sudah dapat diterima dengan baik. Namun masih dibutuhkan kegiatan lainnya untuk terus memberikan dorongan motivasi peserta dalam mengembangkan inovasi-inovasi pembuatan APE di Kabupaten Purwakarta.
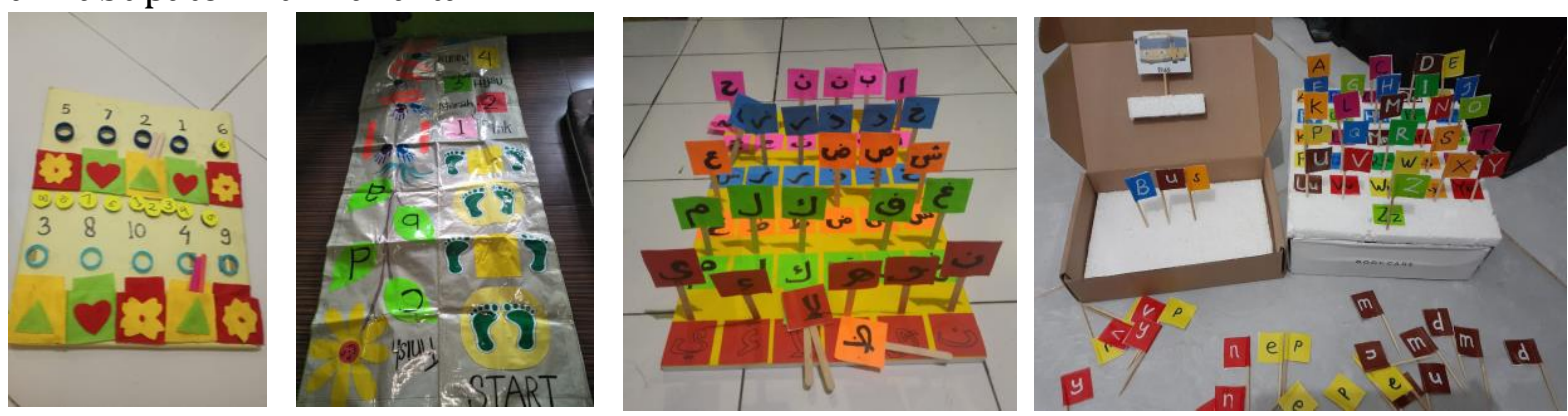

Gambar 1. Hasil Pembuatan APE
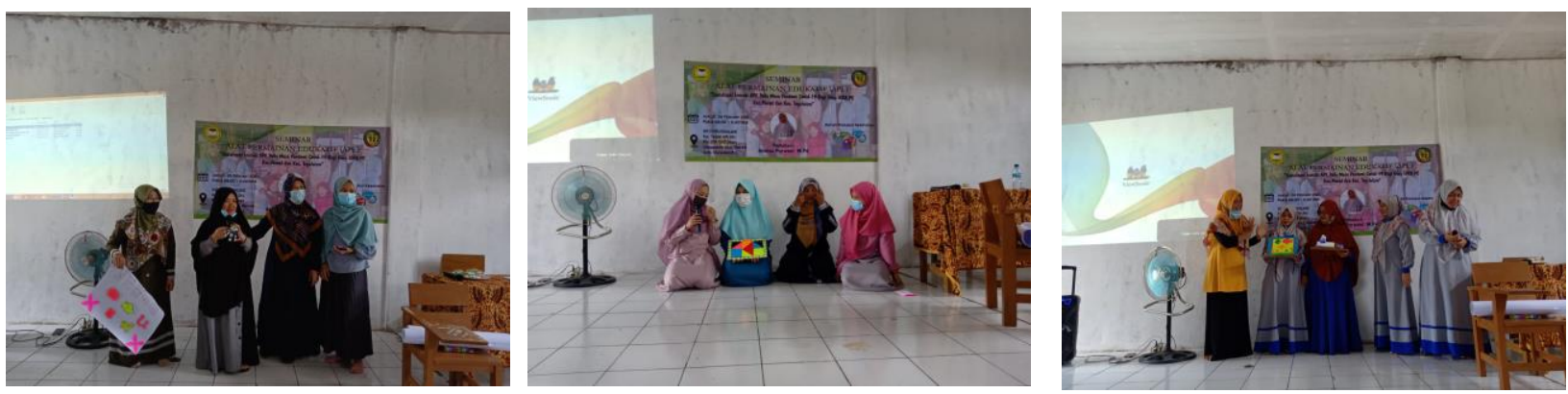

Gambar 2. Presentasi Hasil Pembuatan APE

\section{KESIMPULAN}

Hasil sosialisasi ini menunjukkan bahwa peningkatan pengetahuan serta keterampilan dalam membuat inovasi APE untuk pembelajaran anak usia dini terlaksana dengan efektif. Kegiatan ini dilakukan dalam dua tahap yaitu presentasi dan pelatihan, ini berhasil meningkatkan pengetahuan dan pemahaman peserta dalam kegiatan ini, selain itu peserta juga dapat mengeksplorasi APE yang sudah dibuat oleh teman sejawat lainnya sehingga ketika di lembaganya masing-masing dapat mengembangkan ide dari bahan lain menyesuaikan dengan ketersediaan bahan dan alat yang tersedia di lembaganya untuk membuat media yang sama dengan peserta lainnya. Keterbatasan pada kegiatan ini peserta sangat dibatasi karena acara dilaksanakan masih dalam masa pandemi covid-19 tentu saja seharusnya kegiatan ini dapat diikuti oleh seluruh guru RA se-kecamatan Plered dan Tegalwaru tetapi kegiatan ini sangat dibatasi karena terbatasnya ruang dan hanya bisa perwakilan dari masing-masing lembaga RA khusus daerah kecamatan Plered dan Tegalwaru.

\section{UCAPAN TERIMA KASIH}

Terimakasih kami ucapkan kepada sejumlah pihak yang turut membantu atas kelancaran kegiatan ini, bapak ketua STAI DR. KH. EZ Muttaqien, mahasiswa STAI DR.KH.EZ Muttaqien, ketua PC IGRA Kecamatan Plered dan Tegalwaru, Guru-guru perwakilan dari RA kecamatan Plered dan Tegalwaru. Juga terimakasih kepada semua pihak yang telah 
membantu baik materil maupun imateril atas terselenggaranya kegiatan pengabdian kepada masyarakat yang kami laksanakan.

\section{DAFTAR PUSTAKA}

Fauziyah. (2021). Menyaipkan Satuan Paud Dalam Kondisi Darurat. Madiun: Bayfa Cendikia. Latuconsina, H. (2014). Pendidikan Kreatif. Jakarta: Gramedia.

Nurhayadi, Y., \& Aditiya Agasi, A. (2020). Pengarahan Tentang Pentingnya Pendidikan Usia Dini Di Kampung Bulak, Kecamatan Pondok Gede, Bekasi. Uhamka, 1.

Rahayu, A. D., \& Syahidul Haq, M. (2021). Sarana dan Prasarana Dalam Mendukung Pembelajaran Daring Pada Masa Pandemi Covid-19. Inspirasi Manajemen Pendidikan, 9. Widiaswori, E. (2020). 101 Kesalahan Guru Dalam Pembelajaran. Yogyakarta: Araska. 